NBER WORKING PAPER SERIES

\title{
THE DISTRIBUTION OF PUBLIC SECTOR WAGE PREMIA: NEW EVIDENCE USING QUANTILE REGRESSION METHODS
}

\author{
James M. Poterba \\ Kim S. Rueben
}

Working Paper No. 4734

\section{NATIONAL BUREAU OF ECONOMIC RESEARCH 1050 Massachusetts Avenue \\ Cambridge, MA 02138 \\ May 1994}

We are grateful to the Center for Advanced Study in Behavioral Sciences, the National Science Foundation, and the MIT World Economy Laboratory for research support, and to Moshe Buchinsky, Gary Chamberlain, Jonathan Gruber, Lawrence Katz, Jeff Zax, and especially Finis Welch for helpful discussions. This paper is part of NBER's research program in Public Economics. Any opinions expressed are those of the authors and not those of the National Bureau of Economic Research. 
NBER Working Paper \#4734

May 1994

\title{
THE DISTRIBUTION OF PUBLIC \\ SECTOR WAGE PREMIA: NEW \\ EVIDENCE USING QUANTILE \\ REGRESSION METHODS
}

\begin{abstract}
This paper documents the changing pattern of wage differentials between state and local government employees and their private sector counterparts during the 1979-1992 period. While the relative wages of women employed in the two sectors changed very little during this period, the relative wages of men employed in the state and local sector rose nearly 8\%. There is substantial heterogeneity in the changes in relative wages of public and private sector employees during the 1980s. For highly educated workers, private sector wages rose significantly faster than public sector wages, while for those with at most a high school education, the public sector wage premium increased. We present both least squares and quantile regression estimates of the public sector premium. While the level of this premium is sensitive to our choice of quantile, the change in the premium, and the estimated pattern across skill levels, is not substantially affected by varying the quantile.
\end{abstract}

James M. Poterba

Department of Economics, E52-350 Massachusetts Institute of Technology Cambridge, MA 02139-4307 and NBER
Kim S. Rueben

Department of Economics

Massachusetts Institute of Technology

Cambridge, MA 02139-4307 
Total compensation for state and iocal government workers in the United States rose ten percent faster than that for clvillan workers between 1982 and 1993 . These statistlcs have sparked a publlc pollcy debate on the role of public sector pay increases in contributing to the fiscal problems of state and local governments during this period, and more generally on compensation policy in the public sector. ${ }^{1}$ Much of this debate has proceeded without regard to a voluminous literature in labor economics, beginning with Smith (1977) and surveyed by Ehrenberg and Schwarz (1986), that has estimated the pay premium associated with working in the public rather than the private sector. The recent increase in average public sector compensation is particularly difficult to interpret in light of the well-documented rise in the labor market returns to schooling during the 1980s, and the greater concentration of highly-educated workers in state and loca! government than in the private sector.

Most of the previous research on pay differentials between the public and private sectors focuses on the 1960s and 1970s, a period when public sector employment grew rapidly and unions and collective bargaining diffused in the public sector. Ehrenberg and Smith (1994) summarize these studies as suggesting a public sector wage premium for women, and a small wage penalty for men. The most recent comparison of public and private sector wages, by Katz and Krueger (1991), tracks the evolution of relative wages during the 1979-1988 period. That study

'Examples of recent policy discusslons focusing on this issue include Cox and Brunelll (1992), who attribute fiscal stress to rising public sector pay, and Belman and Heyward (1992), who argue that wages in the public sector are insignificantly different from those in the private sector. 
contrasts the state and local government wage premlum for workers with different educational attainments. It finds that poorly-educated workers enjoyed a growing public sector wage premium during the 1980 s, while better-educated workers faced a shrinking public sector premlum. These findings, which motlvate the current study, underscore the importance of disaggregation in considering relative public and private sector wages.

This paper presents new evidence on the evolution of the state and local government wage premium for different categories of workers during the last decade. We employ quantile regression techniques to explore the distribution of relative wages in the two sectors. We find that while the level of the public sector wage premium varies significantly as one moves across quantiles of the conditional wage distribution, the change in the public sector wage premium is relatively insensitive to the choice of quantile.

This paper is divided into four sections. Section one summarizes recent trends in wages and compensation in state and local government and the private sector. It uses data from the Current Population Survey (CPS) to confirm previous estimates of the average public sector wage premium, for men and women with different leveis of human capital. It also discusses the intertemporal consistency problems that are created by the 1992 change in the CPS questions related to education.

Section two presents quantile regression evidence on both the level of, and change in, the public sector wage premium. The emplrical results suggest that different parts of the relative wage distribution have evolved In different ways during 
the last two decades, and provide further insight on the experience of workers with various levels of human capital. Sectlon three reports alternative estlmates of the public sector wage premlum, based on comparisons of workers in narrowly-defined occupations with similar job responslbilitles in both sectors. Although there are substantial disparities in the estimated public sector premia in different occupations, the broad patterns are consistent with our earlier findings. A brief conclusion suggests a number of directlons for further work.

\section{Compensation \& Wage Differentials: State \& Local Government vs, Private Sector}

Two data sources are widely used to compare the relative earnings of workers in state and local government and the private sector. These are the Employer Cost Index (ECI), which is compiled by the Bureau of Labor Statistics and has included information on total compensation of state and local government employees for the period since 1982, and the Current Population Survey (CPS), which contains individual-level information on the wages and salaries of workers in state and local government as well as the private sector. ${ }^{2}$ This section begins by describing the relative compensation trends shown by the $\mathrm{ECl}$ data. The primary limitation of the $\mathrm{ECl}$ is that it is not possibie to control for worker characteristics in comparing wages and benefits in the two sectors. The remainder of this section, and this paper, therefore

${ }^{2}$ We combine state and local government employees into a single sector. In 1991 , states employed $4.4 \%(5.4 \%$ ) of employed men (women), whlle localitles accounted for $7.6 \%(11.9 \%)$. The higher share of female local employees largely reflects local employment of primary and secondary teachers. 
relies on CPS data to compare the relative public and private sector wages of workers with similar characteristics.

\subsection{Relative Compensation Data from the Emolovment Cost Index}

The BLS Employment Cost Index measures total compensation, wages plus the cost of fringe benefits, for workers in the public and private sectors. These data can be used to compare the average levels of compensation In the two sectors at a point in time, or to compare the relatlve growth rates over time in compensation for a fixed occupational mix of workers. Table 1 presents data from the March 1993 Employment Cost Survey, which show a substantial difference between average compensation in state and local government ( $\$ 24.44$ per hour) and the private sector (\$16.70 per hour). Nearly two thirds of this disparity is the result of higher wages and salaries in the public sector.

Table 1 also presents more disaggregate information on the relative compensation of workers in the two sectors. It divides employees into three categories: white collar, blue collar, and service. ${ }^{3}$ Part of the disparity between the average compensation In the public and private sectors is due to the greater concentration of white coliar workers, $68 \%$ vs. $51 \%$, in state and local government. Even within these broad occupational categories, however, both average

\footnotetext{
${ }^{3}$ More than half of state and local government employees are employed in the productlon of educational servlces. Teachers and most other workers in the education sector are white collar employees. Pollce, fire, and sanitation workers are classified as service workers.
} 
compensation and average wage and salary for state and local employees exceed the comparable magnitudes for private sector workers. The absolute disparitles are greatest for white collar and servlce employees, who receive an average of $\$ 8.00$ and $\$ 8.50$ in additional compensation in the public sector. The percentage difference In compensation is greatest for service workers, for whom total public sector compensation is nearly twice that in the private sector.

$\mathrm{ECl}$ data are available since 1982. They show that the Index of total compensation for private sector workers rose $60.4 \%$, or at a compound annual growth rate of $4.3 \%$, between June 1982 and June 1993. For state and local government employees, the corresponding increase in compensation was $76.2 \%$, which corresponds to an annual growth rate of $5.1 \%$. Most of the difference in compensation growth rates occurred during the mid-1980s.

The primary advantage of $\mathrm{ECl}$ data, reiative to information in the CPS, is that it provides information on fringe benefits as weil as wages and salaries. In 1993, benefit costs averaged $43.8 \%$ of wage costs for public sector workers, and $40.3 \%$ for those in the private sector. Between 1982 and 1993, wages and salaries grew $69.2 \%$ in the public sector, and $52.2 \%$ in the private sector. Thus, both wage and non-wage compensation increased faster for public sector than private sector workers. These summary measures nevertheless suggest that focusing exclusively on the evolution of relative wage levels, as we do below, should capture the broad trends in relative compensation in the two sectors. 


\subsection{Public Sector Wage Premia in the CPS Data}

We foliow in the tradition of Smith (1977) and estimate the wage premium associated with state and local government employment by fitting wage equations on CPS data." Our wage equation relates the logarithm of an individual's hourly wage, $\ln \left(w_{k}\right)$, to a set of individual characteristics $\left(X_{n}\right)$ that can affect marginal productivity, and an indicator variable $\left(\mathrm{SLGOV}_{\mathrm{k}}\right)$ for working in the public sector:

$$
\text { In } w_{k}=X_{k} \beta_{t}+S L G O V_{k} * \delta_{t}+\epsilon_{k}
$$

The set of individual characteristics includes education, experience lage - education 6), marital status, race, residence in an SMSA, as well as an indicator variable for part-time employment. We allow education to affect wages through a set of four categorical variables (EDUC) for number of years of schooling, corresponding to less than twelve years, thirteen to fifteen years, sixteen years, which typically corresponds to completing college, and more than sixteen years. The omitted category is twelve years of schooling, which typically corresponds to completing high school. The wage equation includes linear, quadratic, cubic, and quartic powers of experience. In some equations, we also include a set of control variables for ten broad occupational

\footnotetext{
'Moore and Newman (1991) summarize this literature, and also note that since wage equations estimated on Individual data typically lack information on precise job characteristics, there may be omitted factors, such as the riskiness of some types of public sector jobs, that contribute to wage differentlals.
} 
classifications, such as managerial and technical, sales, or crafts.

We estimate (1) using data from the merged outgoing rotation groups in the CPS for the years 1979-1992. We exclude self-employed individuals from our analysis, because it is difficult to measure their wage rates. We also exclude federal government employees, because they are neither private sector nor state and local government employees." We estimate equation (1) separately for men and women. Changes in the CPS questlonnaire with respect to education, introduced beginning with the 1992 survey, make it impossible to estimate the same wage equation before and after 1991. Prior to 1992, the CPS question about educational attainment asked respondents about the number of years that they had attended school, and whether the final year of schooling had been completed. Beginning with the 1992 survey, the CPS questions focused on the respondent's highest grade completed, with additional questions designed to collect information on degrees

\footnotetext{
6The set of variables included in this wage equation is similar to that in Katz and Krueger (1991, 1992), although our approach is somewhat different. They estimate separate wage equations for workers in the pubilc and private sectors, and then predict average wages in each sector for hypothetical workers with fixed characteristics. We estimate a single wage equation each year for all men, and all women, and impose the same coefficient vector $\beta_{8}$ for the private and public sectors up to a year-specific shift parameter, $\delta_{z}$. This procedure ylelds a parametric estimate of the wage premium assoclated with public sector employment. We further disaggregate this premium, In some cases, Into that part attributable to differences in the returns to schooling and experience across sectors. We always constrain the coefficients on other individual characteristics to be equal across sectors.

If we include federal employees, and allow a separate average wage premlum for these workers, our results on the relative wages of state-local government and private sector employees are not affected. The average wage premium for federai workers, relative to private sector workers, is positive.
} 
obtained. These questions do not elicit the same information from respondents, and we present information in the appendix on the distribution of educational attainment from the two sets of surveys.'

These survey changes imply an Inconsistent classification of individuals across the five categorical variables for educational attainment between 1992 and previous years. This inconsistency will also affect the measurement of experience, which is defined as (age - schooling - 6). In spite of these problems, we estimate the analogue of equation (1) on the 1992 data, and we do not find any evidence of a discontinuity in the estimated public sector wage premium between 1991 and 1992 . The problem of intertemporal inconsistency, however, leads us to focus on the 1979-1991 period when we disaggregate the state and local govemment wage premium by education and experience.

Equation (1) allows the premium for state and local government employees $\left(\delta_{t}\right)$, as well as other coefficients in the wage equation, to vary across years. Figure 1a plots the values of $\delta_{\mathrm{i}}$ from the estimated wage equations for men for the 1979-1992 period. The other coefficients from the estimated wage equations, which are similar to those in other studies using CPS data, are not reported. Figure 1 shows two curves, one corresponding to estimates of $\{1\}$ without occupational controls, the other with such controls. The standard error of each year's estimate is approximately

\footnotetext{
'To illustrate the potentlal differences, consider a respondent who failed second grade, but then successfully completed all subsequent years of schooling and received a high school degree. This respondent would have thirteen years of schooling according to the pre-1992 questions, but would be recorded as having completed high school (12 years of schooling) In the 1992 survey.
} 
0.005. The figure shows that after controlling for worker attributes, men employed in the public sector earned less on average than thelr private sector counterparts in the early 1980s. The estimated magnitude of the private sector premium is sensitive to the inclusion of occupational controls, a point that Belman and Heyward (1992) raise in the popular debate on public sector compensation. For 1980, for example, without such controls the point estimate suggests a private sector premium of twelve percent. With such controls, the premium is approximately seven percent.

The premia shown in Figure 1a contrast with the earlier estimates based on differences in average wages in the Employment Cost Index. In the early 1990s, the CPS data show rough parity between the characteristic-controlled wages of men employed in the public and private sectors. The estimates of $\delta_{t}$ with and without occupational controls display a similar pattern of compression in the differences between public and prlvate sector pay. While the estimates without occupation controls suggest that public sector male workers earned $11.5 \%$ less than their private sector counterparts in 1980, they suggest earnings of only $1.9 \%$ less in 1992 . With occupational controls, the absolute difference narrows, with a change from a $6.6 \%$ deficit (1979) to a $0.3 \%$ premium (1992).

Figure 1b shows the analogous estimates of the year-by-year wage premium

\footnotetext{
We have disaggregated public sector workers Into state employees and local government employees. In 1979, men who worked for local governments earned $2.9 \%(0.8$ standard error) less than those who worked for state governments. This differential declined over the 1979-1991 period, to a local government penalty of $0.6 \%(0.9)$ by 1991 . For women, local governments also pay less well than state governments. The pay penalty changes from $3.7 \%$ in 1979 to $4.2 \%$ in 1991 .
} 
for women employed in state and local government. Both the level of the wage premium, and the time pattern of this premium, are very different than those for men In Figure 1a. Without occupational controls, the public sector appears to pay a premium of between three and five percent to women employees during thls period. With occupational controls, the average wage premium is statistically indistinguishable from zero in the early 1980s and early 1990s, although it rises slightly, to a premium of one and a half percent, in the mid-1980s.

\subsection{Public Sector Wage Premia Stratified bv Educational Attainment}

Katz and Krueger (1991) found substantial differences between the public sector wage premia for those with high school and college degrees. We present further evidence on the llnk between worker attributes and the public sector wage premium by interacting the set of indicator variables for five ranges of educational attainment $\left(E D U C_{p k}\right.$ ) with the indlcator variabie for working in the state and local sector. This yields the equation:

$$
\text { In } w_{k}=X_{k} \beta_{l}+\sum_{k=1}^{s} S L G O V_{k} E E D U C_{k} * \delta_{k}+\epsilon_{k} \text {. }
$$

The set of coefficients $\delta_{k}$ measure the public sector wage premium for each educational group.

To avoid the problems of intertemporal inconsistency in the CPS education variable between 1992 and earlier years, we estimate equation (2) for 1979, 1985, and 1991. The upper panel presents estimates of $\delta_{k}$ for men, and illustrates important 
differences in the level and evolution of the public sector wage premium across educational groups. For men with a high school education or less, there was a public sector pay penalty at the beginning of the 1980s, but it largely disappeared during this decade. The premium for such employees with a high school degree was -.125 in 1979, but it was positive, +.021 , in 1991 . This reflects a net change of more than fourteen percent in the public sector premium. For men with college degrees, the public sector pay penaity also declined, but did not disappear, during the 1980s. In 1979, men with a college degree faced a public sector pay penalty of .130 . It declined to .077 by 1991 . The public sector wage penalty for men with post-college education did not follow the pattern for those with college degrees or less education. It widened by $4.7 \%$ from 1979 to 1985, and then remained constant between 1985 and 1991. There was consequently a net expansion in the public sector pay penalty for post-college educated men during the 1980s.

The lower panel of Table 2 presents estimates of $\delta_{k}$ for women. The pattern of changes in the public sector wage premia across educational classes resembles that for men, although the leveis are different. High school educated women experienced an increase in their public sector pay premium from .016 in 1979 to .073 in 1991. Although high school educated women did not face the public sector pay penalty that hlgh school educated men faced at the end of the 1970s, they did share in their

\footnotetext{
'Katz and Krueger (1991) limlt their analysis to those with either 12 years or at least 16 years of schooling. They report relatively little change, or a slight increase, in the public sector pay penalty for men with college or post-college education durlng the 1979-1987 period. Table 2 shows there are differences in the relative wage experience of those with just 16, and more than 16, years of schooling.
} 
relatlve public sector wage appreciation. For highly-educated women, the public sector wage premium of the late 1970s largely disappeared by 1991. A wornan with a college degree was predicted to earn $9.2 \%$ more in the public than in the private sector in 1979, but no more In 1991. For women with post-college education, the estlmated wage premium decllned from $14.4 \%$ to $3.4 \%$.

\section{Exolorina Public and Private Sector Wage Distributions}

The recent decline in the real wages of workers with relatively low skill levels, documented for example by Bound and Johnson (1992), Katz and Murphy (1992), and Murphy and Weich (1992), has helghtened interest in the lower tails of the both the private and public sector wage distributions in the United States. The possibility that political factors constrain the pay of highly-skilled public sector employees, which is discussed by Joskow, Rose, and Shephard (1993) and Ritchle and Gold (1992), suggests the value of examining the upper tails of the distributions as well. Katz and Krueger $(1991,1992)$ discuss a number of factors that may contribute to greater rigidity over time, as well as less dispersion at a point in time, in public sector wages than their private sector counterparts. In this section, we present new evidence on the distribution of relative wages in the public and private sectors.

There are three sources of differences In the public and private sector wage distributions: differences in the dlstributions of worker characteristlcs in the two sectors, differences in the returns to various worker charateristics across sectors, and 
differences in the distributions of unexplained wage residuals across sectors. ${ }^{10}$ To explore the distribution of human capital attributes in the two sectors, we computed the distribution of predicted wages in each sector using the coefficients from a wage equation estimated only for private sector employees in 1991. These dlstributions for men and women are shown in Figure 2. For both men and women, the distribution of predicted hourly wages in the public sector is right-shifted relative to the analogous private sector wage distribution, indicating that there are proportionally more workers with hlgh levels of educatlon and experience in the public than in the private sector.

The regression coefficients in Table 2 describe the average public sector wage premium for individuals with different levels of education. They do not consider the possibility that the distribution of actual wages around their predicted values differs across sectors. In fact, both the unconditional and conditional wage distributions in the public sector are more compressed than those in the private sector. To lllustrate this, we estimated separate wage equations for public and private sector workers, without occupational controls, using the 1979 and 1991 CPS data sets. The estimates for men show that for 1991, $\sigma_{\text {pav }}=.440$, while $\sigma_{a}=.410$. For women, the analogous estimates are $\sigma_{p+v}=.414$ and $\sigma_{\alpha}=.387$. There has been relatively little change in the relative dispersion of the public and private sector wage distributions for men, although there is some evidence of growing private relative to

${ }^{10} \mathrm{Juhn}$, Murphy, and Plerce (1993) decompose changes in the wage distribution into these three components. 
publlc sector dispersion for women. ${ }^{11}$

Estlmating the publlc sector wage premium is complicated by the presence of different variances in the wage distributions in the public and private sectors. To illustrate this, consider a case in which the mean and median wages in the two sectors, conditional on worker attributes, are identical, but the private sector has greater wage dispersion. While comparisons of the mean or median conditional wage will show no public sector premium, comparisons of higher quantiles will show a public sector pay penalty, while lower quantiles will show a public sector premium.

Similar concerns about differences in the variance of conditional wage distributions between the union and non-union sectors led Chamberlain (1994) to study the union wage premium at various quantiles. Buchinsky $(1994 a, b)$ has developed related arguments for applying quantile-based methods to studying the returns to education and the changing distribution of private sector wages more generally. We follow this approach and estimate quantile regression models corresponding to equations (1) and (2) above.

We assume that the qth quantile of the conditional wage distribution is a linear function of individual attributes $\left(X_{k}\right)$ :

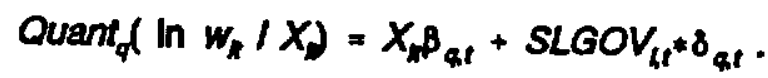

Koenker and Bassett (1978) demonstrate that quantile regression models can be estlmated by finding the vector $\left(\beta_{a, b} \delta_{a t}\right)$ that minimizes

\footnotetext{
11 In 1979, for men, $\sigma_{\text {ptv }}=.408$ and $\sigma_{\alpha}=.374$, while for women, $\sigma_{\text {ptv }}=.362$
$\sigma_{\alpha}=.344$. and $\sigma_{\mathrm{d}}=.344$.
} 


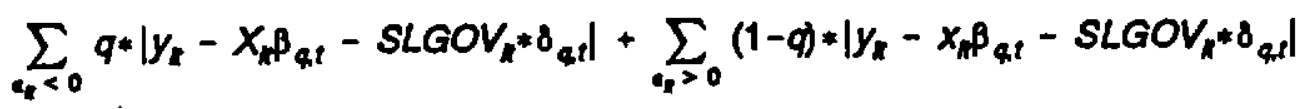

using linear programming techniques. ${ }^{12}$

Figure 3 presents estimates of $\delta_{4 t}$ from quantile regressions with $q=.10, .25$. $.50, .75$, and .90 for the years $1979-1991$. The corresponding point estimates, along with OLS estimates, are shown in Table 3. The estimated private sector wage premium for men, estimated by median regression, is about two percent greater than that estimated by ordinary least squares. At $q=.10$, the estimated private sector premium for the early 1980 s is negligible, even though the OLS estimates suggest an $11 \%$ wage disparity between state and local government and the private sector. Similarly, the results for $q=.90$ show a public sector wage disadvantage of more than twenty percent in the early 1980s, declining to eight percent by 1991. In most years, the absolute difference between the wage premium estimated with median regression and that with $q=.90$ is smaller than that between the median regression and $q=.10$.

The quantile regression results for women are similar to those for men. The median regression results are similar to the least squares coefficients, and the ievel of the estimated public sector wage premium depends on the vaiue of $q$, but the time series pattern of wage premia is similar for most quantiles. There is one exception:

${ }^{12}$ Chamberlain (1994) proposes an alternative minimum-distance estimator for quantile regression models, which requires stratifying the data into cells, computing cell quantiles, and then fitting a conditional quantile function to these cell quantiles. Where feasible, we estimated the quantlle regression models presented below by this method, with results quite similar to those we report, which are based on the linear programming algorithm. 
the low-quantile estimates of the wage premium display an upward trend during the 1979-1991 period. The median regression estimate of the public sector wage premium in 1991 (.039) Is similar to that in $1979(.041)$. For the lowest quantile $(q=.10)$, however, the 1991 premium $(.092)$ is substantially greater than the 1979 value (.061). The estimated premium at $q=.10$ also widens more during the mid1980s, to .137 in 1988, than the premium estimated using either OLS or median regression.

The quantile regression results suggest two findings. First, the level of the estimated public sector wage premium is sensitive to the choice of quantile. There is a much smaller penalty associated with working in the public sector at low than at high quantiles. The pattern of quantile regression coefficients for the state and local wage premium resembles Chamberlain's (1994) findings for union wage effects, with larger positive effects at lower quantiles. Second, in spite of our finding regarding the level of the public sector pay premium, however, the time series pattern of state and local government wage premia from the quantile regressions tracks that from the least squares regressions very closely, regardless of which value of q we choose.

We do not report standard errors for each of the coefficient estimates in Table 3, because these standard errors are roughly constant from year to year for each quantile. We do present the average of the twelve estimated standard errors for each set of quantile coefficients. ${ }^{19}$ These standard errors are computed from the analytic

\footnotetext{
13 In a typical column in Table 3, more than half of the estimated year-specific standard errors equal the average standard error reported in the bottom row.
} 
variance-covariance matrix, $V\left(\beta_{q, e}\right)=\left(X^{\prime} X\right)^{-1}\left(X^{\prime} W^{\prime} W^{\prime} X\right)\left(X^{\prime} X\right)^{-1}$, where $W=\operatorname{diag}\left[\left(\left.q^{*}\right|_{c>0}\right.\right.$ $\left.+(1-q) \Psi_{f<0} / / f_{f}(0)\right]$ and $f_{f}(0)$ is a kernel estimator of the density of the residual distribution at zero. ${ }^{14}$ The standard errors vary relatively little across years, but do vary across quantlles within each year. The regression coefficients corresponding to more extreme quantiles are estlmated less precisely than those closer to the median.

Several recent studies, for example Rogers (1992), have considered the estimation of quantile regression standard errors, and compared the performance of this analytical procedure with alternatives such as bootstrap estimation. We also calculated bootstrap standard errors for some of our quantile coefficient estimates. Table 4 reports the $\delta_{a,}$ coefficients, and both sets of standard errors, for the 1979 and 1991 samples. The results show that the analytic and bootstrap standard errors are very similar for both years. In no case do the two approaches yield differences in the estimated standard errors of more than .001 , which corresponds to less than a $25 \%$ dlfference for virtually all coefficients.

There remains a question of whether our quantile regression results are solely driven by differences in conditional variances across sectors. Applying a result in Chamberlain (1994), if the conditional log wage distributlons for the private and public

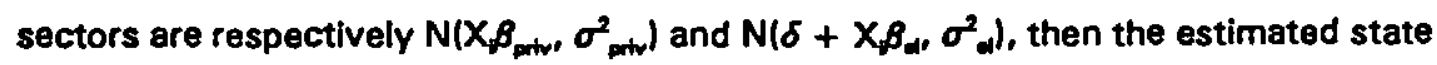
and local wage premium at the qth quantile will equal $\delta+X_{1}\left(\beta_{\mathrm{da}}-\beta_{\mathrm{par}}\right)+q^{*}\left(\sigma_{\mathrm{d}}-\sigma_{\mathrm{pqu}}\right)$.

\footnotetext{
${ }^{14}$ The density $f,(0)$ is estimated by ranking residuals, finding the residuals with ranks $N^{*}=q N-N^{.5}$ and $N^{* *}=q N+N^{.6}$, and calculating $\left[\epsilon_{N^{*}} .-\epsilon_{N^{*}}\right] / 2 N^{.5}$. This procedure is modified when $\mathrm{qN}+\mathrm{N}^{.5}>\mathrm{N}$, or $\mathrm{qN}-\mathrm{N}^{.5}<0$. Rogers (1992) discusses this algorlthm in more detail.
} 
Our estimated differences In the conditional variances across sectors are not large enough to explaln the results in Table 3 if $\beta_{\mathrm{potr}}=\boldsymbol{\beta}_{\mathrm{\alpha}}$. The differential variance contribution to the difference between $\beta_{.90,8}$ and $\beta_{.10,8}$ is $.80 *\left(\sigma_{\text {paiv }}-\sigma_{w}\right)$, or less than .03 for both men and women. The actual 1991 difference in these coefficients is .157 (men) and .135 (women). This suggests, as our estimates of $\delta_{n}$ by educational level confirm, that there are differences in the coefficient vector $\beta$ across sectors.

We also apply quantile methods to study the public sector wage premium conditional on various levels of educational attainment, and conditional on various levels of experience. The results of estimating equation (2) by quantile methods are presented in Table 5. The results show that there is relatively little difference across quantiles in the 1979-91 change in the public sector premium. The level of the public sector wage premium, however, differs across quantiles in the same way as in Table 3. For those with less than a high school degree, there are also differences in the changes in the wage premla at different quantiles, but there is no apparent pattern. For those at high quantiles $(q=.90)$, the increase in the public sector premium is smaller than that for others in the distribution.

The lower panel of Table 5 presents results for women analogous to those in the upper panel for men. The most striking examples of differences in the change in the public sector premium as we vary the quantile value are found for women with college or post-graduate degrees. For those with a college degree, the public sector pay premium in the 10 th percentile narrowed from $13.6 \%(1979)$ to $10.3 \%(1991)$. For those in the 90th percentile, however, the pay penalty expanded substantially, 
from $-1.4 \%$ in 1979 to $-11.0 \%$ in 1991. A similar pattern Is observed for those with post-graduate degrees.

We also explored the distribution of public sector wage premia for workers with different levels of experlence. Instead of the quartic equation in experlence, which is included in the $X_{k}$ matrlx of equations (1) and (2), we stratified CPS respondents into four experience groups: those with less than 11 years of experience, 11-20 years, 21 30 years, and more than 30 years. We then interacted these four indicator variables $\left(E X P E R_{p_{2}}\right)$ with an indicator for working in state and local government, to measure the public sector premium for workers at different experience levels. This yieids the following wage equation:

$$
\text { In } w_{k}=X_{k} \beta_{i}+\sum_{k=1}^{4} S L G O V_{k} * E X P E R_{k} * \delta_{k}+\epsilon_{k}
$$

Table 6 shows the results of estimating (5) by quantile regression. For men, there is no evidence that the level of the public sector wage premia depends significantiy on experience, or that the pattern of such premia across experience categories changed substantially during the 1980s. For women, however, the results do suggest that those with more experience fared relatively better than those who were recently hired in the public sector. For female employees with less than ten years of experience, the public sector pay premlum narrowed from $5.5 \%$ to $1.8 \%$ between 1979 and 1991. For those with more than thirty years of experience, the premium grew from $7.2 \%$ to $8.5 \%$. There is some evidence, based on comparison 
of various quantile results, that high-experience women at the bottom of the conditional wage distribution recorded larger relative gains than those elsewhere in the distribution. For men, there is some evidence that the change in the public sector premlum, conditional on experience, depended on their location in the conditional wage distribution. For those with less than ten years of experience, the public sector pay premium grew much more for those near the top of the wage distribution than those at lower strata.

\section{Public and Private Sector Wages in Soeciflc Occupations}

Our analysis so far has compared individuals with similar human capital attributes, but we have not considered occupational characteristics, such as the riskiness of some public safety jobs, that might lead to a pay differentials for public sector work. To address such differences, in this section we present detailed comparisons of relative public and private sector wages for several occupational categories with substantial employment in both sectors.

We begin by pooling adjacent years of CPS data, for $1979 / 80$ and $1990 / 91$. to increase our effective sample size. ${ }^{18}$ For each of these data sets, we then seiect respondents in the various occupational categories, estimate a wage equation similar

\footnotetext{
${ }^{15}$ Given the CPS sampling pattern, which surveys Individuals for four consecutive months, leaves them out of the survey for eight months, and then includes them again for another four months, half of the Individuals who participate in the survey in a given month of one year will will also be surveyed in the same month the next year. To avold spurious double-counting of these individuais, we exclude the 1980 responses of such individuals in our 1979/80 data set, and the 1990 responses of such individuals in our 1990/91 data set.
} 
to (1) above, and report the estimated value of $\delta_{0, t e}$ where subscript 0 denotes occupation and subscript t corresponds to either $1979 / 80$ or $1990 / 91$. The resulting coefficient estimates broadly confirm our earlier evidence that the public sector pay premium is most pronounced in traditional low-skiil occupatlons.

The upper panel of Table 7 presents results for men in several occupations that are common in both the public and private sectors. For orderlies, our estimates suggest a public sector pay premium of $17.3 \%$ in both $1979 / 80$ and $1990 / 91$. For cleaners, the pay premium widens from $2.1 \%(1979 / 80)$ to $9.1 \%(1990 / 91)$, and for truck drivers, a substantlal pay penalty of $19.1 \%$ in $1979 / 80$ is erased during the subsequent ten years, with an estimated, but statistically insignificant, pay penalty of $1.7 \%$ in 1990/91. For the highest skill occupation that we consider, doctors, the point estimates suggest a growing public sector pay penaity but we cannot reject the null hypothesis of pay equality across sectors for either $1979 / 80$ or $1990 / 91$.

The last two rows in the first sub-panel of Table 7 present results for teachers. We include special education and pre-klndergarten teachers in our classification of primary and secondary teachers. Post-secondary teachers are professors and instructors in universities, community colleges, and other institutions of higher learning. For primary and secondary teachers, the results suggest a substantial public sector premium: $15.4 \%$ in 1979/80, $16.8 \%$ in 1990/91. Interpreting these findings is clouded, however, by the difficulty of comparing public and private schoois. Because private schools may offer less difficult work environments than public schools, part of the estimated public sector premium may reflect differences In job 
characteristics. Private schools also typically require fewer credentials, beyond a college degree, than their public sector counterparts. For post-secondary teachers, we estlmate a public sector pay premium of between slx and seven percent in both data sets.

The lower panel of Table 7 presents parallel evidence for women employed in similar occupations in the public and private sectors. The resuits for both orderlies and cleaners confirm the earlier findings for men, and there is weak evidence, based on the results for cleaners, receptionists, secretaries, and typists, of a growing public sector pay premium during this period. For nurses, a relatively high-skill occupation, we are not able to reject the null hypothesis of equal pay in the two sectors.

The results for female teachers differ somewhat from the results for men. For primary and secondary teachers, the point estimates suggest a substantial public sector pay premium, with weak evidence of a widening pay premium over the twelve years we consider. For post-secondary teachers, the estimates suggest that a substantial pay premium in $1979 / 80$ largely disappeared by the end of our sample.

\section{Conclusions}

This paper presents new evidence on the evoiution of the pay differential between state and local government and the private sector during the 1980s. It emphasizes changes in the distribution as well as the average level of this pay differential. For men, the results suggest that a substantial private sector premium at the beginning of the 1980s was largely eradicated during the 1979-1992 period. 
For women, there is little evidence of a change In the relationship between public and private sector wages. Most of this analysis has focused on wages and salaries, using data from the Current Population Survey.

We have not considered the potentlal selection biases that plague studies of Inter-sectoral wage differences, whether between the public and private sectors or the union and non-union sectors. This Is because we have not found variables that are iikely to affect the probability of public sector employment, but not public sector wages, and that could consequently be used to identlfy selection models.

One natural avenue for extending this work would involve more detailed consideration of fringe benefits in the public and private sectors. Public sector workers are more likely to be covered by defined benefit pension plans, and are more likely to receive a number of other fringe benefits than their private sector counterparts. There is little systematic evidence, however, on how the value of such fringes for comparable workers in the oublic and private sectors has changed over time. Moreover, this paper has not considered the possibility that the availability of benefit packages changed in different ways for different classes of workers, for example those with college degrees versus those with high school degrees.

A second issue we have not explored is the relative contribution of changes in public sector wages, and changes In prlvate sector wages, to movements in the public-private pay differentlal. Evidence from previous studies of private sector pay. however, suggests that much of the change in relative wages for those with low educational attainment is due to worsening wage prospects in the private sector, 
combined with less pronounced changes in public sector real wages.

A final direction for further analysis is the link between fiscal institutions, such as balanced budget amendments or expenditure limitation laws, and the evolution of public sector pay. Compensation costs account for nearly two thirds of expenditures by state and local governments in the United States, and to the extent such laws affect public spending, they are likely to affect wages and/or employment In the public sector. Research directed at this issue is currently underway. 


\section{REFERENCES}

Beiman, Dale, and John Herwood, 1992. The Truth About Public Emplovees: Underoaid or Overpaid. Washington: Economic Policy Institute.

Bound, John, and George Johnson, 1992, "Changes in the Structure of Wages During the 1980s: An Evaluation of Alternative Explanations," American Economic Review 82, 371-392.

Braden, Bradley R., and Stephanie L. Hyland, 1993, "Cost of Empioyee Compensation in the Public and Private Sectors," Monthly Labor Review (May), 14-21.

Buchinsky, Moshe, 1994a, "Changes in the U.S. Wage Structure, 1963-1987: Application of Quantile Regression," Econometrica 62, 405-458.

Buchinsky, Moshe, 1994b, "The Evolution of Women's Return to Education in the U.S.: Exploration by Quantile Regression Analysis with Nonparametric Correction for Sample Section Bias," mimeo, Yale University.

Chamberlain, Gary, 1994, "Quantile Regression, Censoring, and the Structure of Wages," in C. Sims and J.J. Laffont, eds., Proceedings of the Sixth World Conaress of the Econometric Society New York: Cambridge University Press.

Cox, Wendell, and Samuel A. Brunelli, 1992, America's Protected Class (Washington: American Legislative Exchange Councill.

Ehrenberg, Ronald G., and Robert S. Smith, 1994, Modern Labor Economics, Fifth Edition (New York: Harper Collins).

Ehrenberg, Ronaid G., and Joshua L. Schwarz, 1986, "Pubiic Sector Labor Markets," in O. Ashenfelter and R. Layard, eds.. Handbook of Labor Economics, Volume II (Amsterdam: Elsevier Sclence Publishers), 1219-1268.

Hogg, Robert V., 1975, "Estimates of Percentile Regression Lines Using Saiary Data, " Journal of the American Statistical Association 70 (March), 56-59.

Jaeger, David A., 1993, "The New Current Population Survey Education Variable: A Recommendation," University of Michlgan, Popuiation Studies Center, Working Paper 93-289.

Joskow, Paul, Nancy Rose, and Andrea Shephard, 1993, "Regulatory Constraints on CEO Compensation." Brookings Papers on Economic Activitv: Microeconomics, 1993:1, 1-58. 
Katz, Lawrence F., and Alan B. Krueger, 1991, "Changes in the Structure of Wages in the Public and Private Sectors," in Ronaid Ehrenberg, ed., Research in Labor Economics, Volume 12 (Greenwich, CT: JAl Press), 137-172.

Katz, Lawrence F., and Alan B. Krueger, 1992, "Public Sector Pay Flexibility: Labor Market and Budgetary Consideratlons," mimeo, Harvard University.

Katz, Lawrence F., and Kevin M. Murphy, 1992, "Changes in Relative Wages, 1963. 87: Supply and Demand Factors," Quarterly Journal of Economics 107, 35-78.

Koenker, Roger and Glibert Bassett, 1978, "Regression Quantiles," Econometrica 46, 33-50.

Moore, William J. and Robert J. Newman, 1991, "Government Wage Differentials in a Municipal Labor Market: The Case of Houston Metropolitan Transit Workers," Industrial and Labor Relatlons Review 45 (October 1991), 145-153.

Murphy, Kevin M., and Finis Welch, 1992, "The Structure of Wages," Quarterly Journal of Economics 107, 285-326.

Ritchie, Sarah, and Steven D. Gold, 1992, "State and Local Employment in the 1980s: How Did It Grow?," State Fiscal Briefs No. 7, Albany, NY: Center for the Study of the States.

Rogers, William H., 1992, "Quantile Regression with Bootstrapped Standard Errors," STATA Technical Bulletin 9, 16-19.

Smith, Sharon P., 1977, Equal Pay in the Public Sector: Fact or Fantasy (Princeton, NJ: Industrial Relations Section).

U.S. Department of Labor, Bureau of Labor Statistics, 1993, Employment Cost Indexes and Levels. 1975-1993, Bulletin 2434 (Washington, D.C.: U.S. Government Printing Office). 
Table 1: Employee Compensation Costs, March 1993

\begin{tabular}{|c|c|c|c|c|}
\hline & \multicolumn{3}{|c|}{ Occupational Category } & \multirow[b]{2}{*}{ Total } \\
\hline & $\begin{array}{l}\text { White } \\
\text { Collar }\end{array}$ & Bive Collar & Service & \\
\hline \multicolumn{5}{|l|}{ State \& Local Government: } \\
\hline Total Compensation & $\$ 27.67$ & $\$ 18.78$ & $\$ 17.04$ & $\$ 24.44$ \\
\hline Wages \& Salaries & 19.72 & 12.13 & 10.83 & 17.00 \\
\hline Fraction of Employees & $68 \%$ & $12 \%$ & $20 \%$ & $100 \%$ \\
\hline \multicolumn{5}{|l|}{ Private Industry: } \\
\hline Total Compensation & $\$ 19.67$ & $\$ 16.43$ & $\$ 8.54$ & $\$ 16.70$ \\
\hline Wages \& Salaries & 14.32 & 11.01 & 6.48 & 11.90 \\
\hline Percent of Employees & $51 \%$ & $32 \%$ & $17 \%$ & $100 \%$ \\
\hline
\end{tabular}

Sources: U.S. Department of Labor(1993), pages 12-16. Fraction of employees correspond to 1992 percents and are from Braden and Hyland (1993), page 17. 
Table 2: Differences in Return to Educational Attainment Between State and Local and Private Sector Employees

\begin{tabular}{|c|c|c|c|}
\hline \multirow[t]{2}{*}{ Education Level } & & & \\
\hline & 1979 & 1985 & 1991 \\
\hline & \multicolumn{3}{|c|}{ Men } \\
\hline $\begin{array}{l}\text { Less than } 12 \text { years } \\
\text { completed }\end{array}$ & $\begin{array}{l}-.067 \\
(.010)\end{array}$ & $\begin{array}{l}-.027 \\
(.012)\end{array}$ & $\begin{array}{l}.046 \\
(.015)\end{array}$ \\
\hline $\begin{array}{l}\text { High School Degree } \\
\text { (12 years completed) }\end{array}$ & $\begin{array}{l}-.125 \\
(.008)\end{array}$ & $\begin{array}{l}-.053 \\
(.008)\end{array}$ & $\begin{array}{l}.021 \\
(.008)\end{array}$ \\
\hline $\begin{array}{l}\text { Some College } \\
\text { (13-15 years completed) }\end{array}$ & $\begin{array}{l}-.101 \\
(.010)\end{array}$ & $\begin{array}{l}-.050 \\
(.011)\end{array}$ & $\begin{array}{l}.020 \\
(.010)\end{array}$ \\
\hline $\begin{array}{l}\text { College Degree } \\
\text { (16 years completed) }\end{array}$ & $\begin{array}{l}-.130 \\
(.011)\end{array}$ & $\begin{array}{l}-.150 \\
(.012)\end{array}$ & $\begin{array}{l}-.077 \\
(.011)\end{array}$ \\
\hline \multirow[t]{2}{*}{$\begin{array}{l}\text { Post-Graduate Degree } \\
\text { (More than } 16 \text { years) }\end{array}$} & $\begin{array}{l}-.063 \\
(.008)\end{array}$ & $\begin{array}{l}-.110 \\
(.010)\end{array}$ & $\begin{array}{l}-.100 \\
(.010)\end{array}$ \\
\hline & \multicolumn{3}{|c|}{ Women } \\
\hline $\begin{array}{l}\text { Less than } 12 \text { years } \\
\text { completed }\end{array}$ & $\begin{array}{l}.047 \\
(.010)\end{array}$ & $\begin{array}{l}.107 \\
(.013)\end{array}$ & $\begin{array}{l}.106 \\
(.015)\end{array}$ \\
\hline $\begin{array}{l}\text { High School Degree } \\
\text { (12 years completed) }\end{array}$ & $\begin{array}{l}.016 \\
(.006)\end{array}$ & $\begin{array}{l}.065 \\
(.007)\end{array}$ & $\begin{array}{l}.073 \\
(.007)\end{array}$ \\
\hline $\begin{array}{l}\text { Some College } \\
\text { (13-15 years completed) }\end{array}$ & $\begin{array}{l}.008 \\
(.008)\end{array}$ & $\begin{array}{l}.016 \\
(.009)\end{array}$ & $\begin{array}{l}.007 \\
(.008)\end{array}$ \\
\hline $\begin{array}{l}\text { College Degree } \\
\text { (16 years completed) }\end{array}$ & $\begin{array}{l}.092 \\
(.009)\end{array}$ & $\begin{array}{l}.044 \\
(.009)\end{array}$ & $\begin{array}{l}-.005 \\
(.008)\end{array}$ \\
\hline $\begin{array}{l}\text { Post-Graduate Degree } \\
\text { (More than } 16 \text { years) }\end{array}$ & $\begin{array}{l}.144 \\
(.012)\end{array}$ & $\begin{array}{l}.046 \\
(.011)\end{array}$ & $\begin{array}{r}.034 \\
(.010) \\
\end{array}$ \\
\hline
\end{tabular}

Notes: Results are from OLS regressions run on data from the Outgoing Rotation Groups of the CPS 1979, 1985 and 1991. Included explanatory variables, described in more detail in the text, are indicator variabies for each education level, experience, marital status, SMSA status and race. Standard errors are reported in parentheses. 
Toble 3; Quentile Recrevilon Extinates of State and Locel Employes Wege Premia

\begin{tabular}{|c|c|c|c|c|c|c|}
\hline \multirow[b]{2}{*}{ Yoor. } & \multirow[b]{2}{*}{ Moen } & \multirow[b]{2}{*}{.10 } & \multicolumn{3}{|c|}{ Quantilo } & \multirow[b]{2}{*}{.80} \\
\hline & & & .25 & .60 & .76 & \\
\hline \multicolumn{7}{|c|}{ Men } \\
\hline 1878 & -.098 & .000 & -.058 & -.124 & -.163 & -.183 \\
\hline 1890 & -.116 &., 008 &. .087 &. .140 & -.178 & -.200 \\
\hline 1881 & -.122 & .005 & -.002 & -.139 & -.180 & -.224 \\
\hline 1892 & -.111 & .014 &. .046 & -.123 &. .178 &. .222 \\
\hline 1983 & -.086 & .038 &. .026 & -.113 & -.171 & -.208 \\
\hline 1884 & -.080 & .048 & -.024 &. .101 & -.165 & -.180 \\
\hline 1888 &. .076 & .048 & -.018 & -.096 & -.147 & -.172 \\
\hline 1980 & -.072 & .068 & -.014 & -.093 & -.140 & -.153 \\
\hline 1987 & -.063 & .086 &. .004 & -.076 & -.117 & -.110 \\
\hline 1888 & .048 & .068 & -.006 &. .073 & -.117 & -.102 \\
\hline 1889 & $\therefore, 045$ & .058 &. .000 & -.065 &. .105 &. .113 \\
\hline 1890 &.,- 036 & .066 & .010 & -.058 & .088 & -.098 \\
\hline 1891 & -.024 & .076 & .018 &. .040 &. .074 & -.081 \\
\hline Avg SE & .006 & .008 & .008 & .005 & .005 & .007 \\
\hline \multicolumn{7}{|c|}{ Women } \\
\hline 1878 & .038 & .001 & .066 & .041 & .002 & -.037 \\
\hline 1880 & .040 & .086 & .080 & .041 & .002 & -.036 \\
\hline 1861 & .030 & .007 & .002 & .031 &. .017 & -.052 \\
\hline 1892 & .028 & .078 & .071 & .034 &. .021 & -.071 \\
\hline 1893 & .037 & .083 & .083 & .043 & -.018 & -.067 \\
\hline 1894 & .040 & .112 & .008 & .050 & -.014 & -.002 \\
\hline 1896 & .062 & .125 & .102 & .061 & -.008 & -.041 \\
\hline 1886 & .053 & .128 & .108 & .057 & -.002 & .046 \\
\hline 1887 & .053 & .136 & .111 & .060 & -.010 & -.048 \\
\hline 1988 & .053 & .137 & .105 & .046 & -.001 & $-.03 \theta$ \\
\hline 1988 & .037 & .089 & .078 & .037 &.- .05 & -.038 \\
\hline 1890 & .042 & .104 & .083 & .047 & .004 & -.034 \\
\hline 1891 & .036 & .092 & .084 & .039 & -.011 & -.043 \\
\hline Avg SE & .004 & .006 & .006 & .008 & .005 & .007 \\
\hline
\end{tabular}

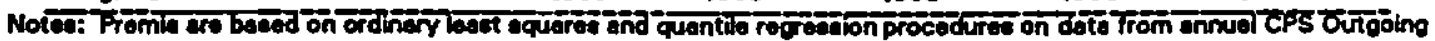

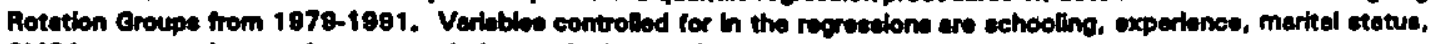
SMSA etetuse and race. Averege enelytio stendard wrore for sech quentive ere reported. 
Table 4: Comparison of Analytic and Bootstrap Standard Errors for Quantile Regression Models

\begin{tabular}{|c|c|c|c|c|c|c|}
\hline & \multicolumn{3}{|c|}{1979} & \multicolumn{3}{|c|}{1991} \\
\hline & $q=.1$ & $q=.5$ & $q=.9$ & $q=.1$ & $q=.5$ & $q=.9$ \\
\hline \multicolumn{7}{|l|}{ Male Workers: } \\
\hline S\&L Premium & .000 & -.124 & -.183 & .076 &. .040 & -.081 \\
\hline Analytic SE & $(.007)$ & $(.004)$ & $(.007)$ & $(.008)$ & $(.004)$ & $(.008)$ \\
\hline Bootstrap SE & $(.006)$ & $(.005)$ & $(.006)$ & $(.009)$ & $\{.004\}$ & $(.009)$ \\
\hline \multicolumn{7}{|l|}{ Female Workers: } \\
\hline S\&L Premium & .061 & .041 & -.037 & .092 & .039 & -.043 \\
\hline Analytic SE & $(.004)$ & $(.003)$ & $(.007)$ & $(.006)$ & $(.004)$ & $(.008)$ \\
\hline Bootstrap SE & $(.004\}$ & $(.004)$ & $(.006\}$ & $(.006)$ & $(.003)$ & $(.007)$ \\
\hline
\end{tabular}

Notes: Bootstrap standard errors are calculated using 20 iterations. Analytic standard errors are calculated using a kernel density function. Both procedures are performed using the STATA software package. 
Tabte 5: Differences in Fotum to Edueethonal Atteinment Botweun Publle and Pityate Sector Employeete Leeet Squeres and Quentile Rogresion Estimetes

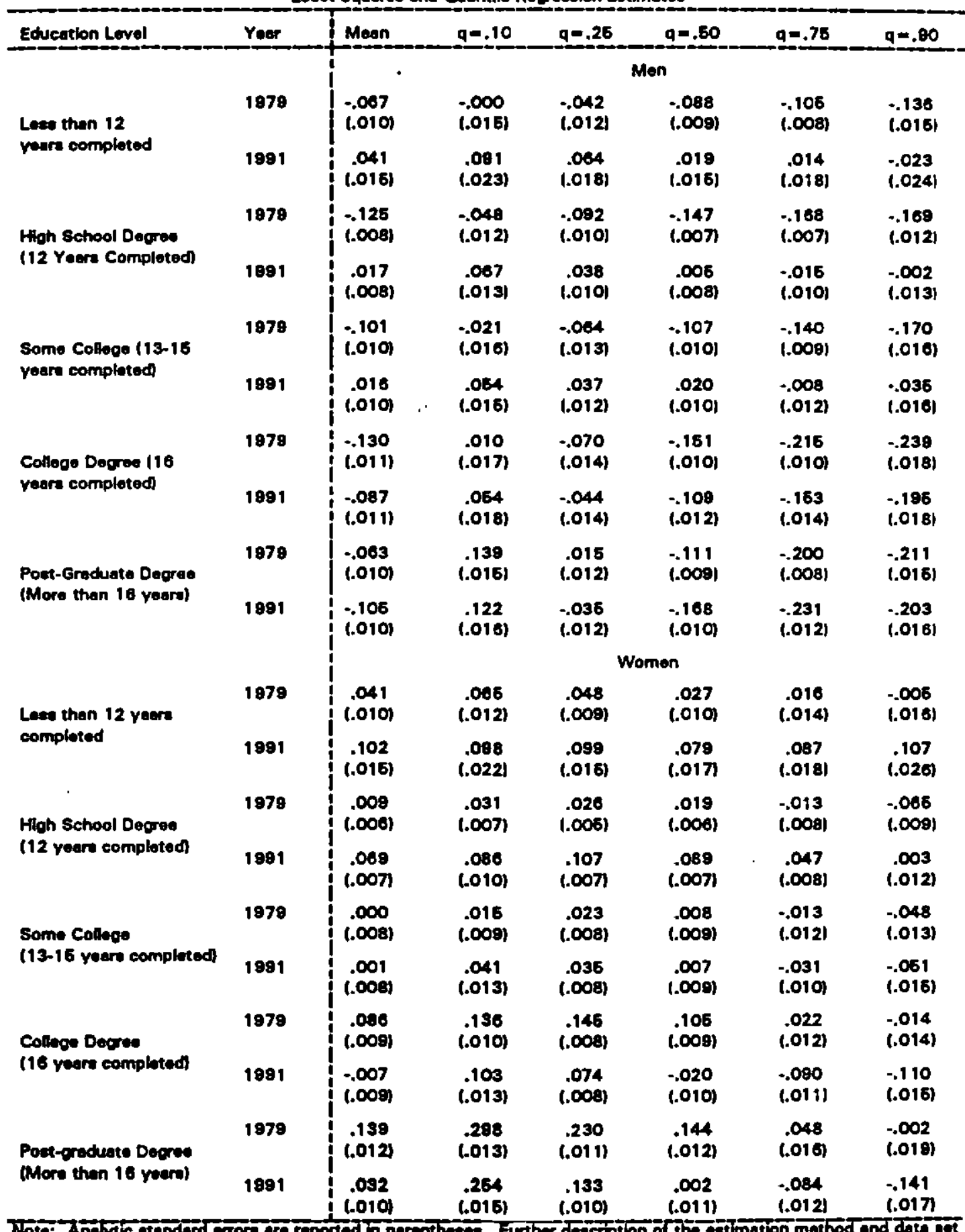

Tote: Antric otanderd wers are reported in parentheaes. Futher decription of the extimation mothod and date ex brovided in the text. 


\section{2}

Table 6: Differences in Rotum 10 Experiance Levela Batweon Publlo ond Privote Sector Emplovese Least Squerse and Quentile Regrosalon Extimajes

\begin{tabular}{|c|c|c|c|c|c|c|c|}
\hline Experiones & Yeer. & Moan & $q=.10$ & $9=.25$ & $9=.60$ & $q=.75$ & $q=.80$ \\
\hline & & \multicolumn{5}{|c|}{ Mon } & \\
\hline \multirow[t]{2}{*}{10 or Leas Yoort } & 1879 & $\begin{array}{l}-.084 \\
1.007\end{array}$ & $\begin{array}{l}-.009 \\
(.009)\end{array}$ & $\begin{array}{l}-.047 \\
1.0049\end{array}$ & $\begin{array}{l}-.082 \\
(.002)\end{array}$ & $\begin{array}{l}-.128 \\
1.007\end{array}$ & $\begin{array}{l}-.157 \\
(.012)\end{array}$ \\
\hline & 1981 & $\begin{array}{l}-.010 \\
(.009)\end{array}$ & $\begin{array}{c}.013 \\
(.011)\end{array}$ & $\begin{array}{l}-.010 \\
(.003)\end{array}$ & $\begin{array}{l}-.014 \\
1.007)\end{array}$ & $\begin{array}{l}-.008 \\
(.011)\end{array}$ & $\begin{array}{l}-.024 \\
(.016)\end{array}$ \\
\hline \multirow[t]{2}{*}{11 - 20 Years } & 1978 & $\begin{array}{l}-.104 \\
(.003)\end{array}$ & $\begin{array}{c}.010 \\
(.011)\end{array}$ & $\begin{array}{r}.064 \\
1.0041\end{array}$ & $\begin{array}{l}-.144 \\
(.002)\end{array}$ & $\begin{array}{l}-.177 \\
(.008)\end{array}$ & $\begin{array}{l}.182 \\
(.014)\end{array}$ \\
\hline & 1981 & $\begin{array}{l}-.024 \\
(.008)\end{array}$ & $\begin{array}{c}.092 \\
(.010)\end{array}$ & $\begin{array}{c}.023 \\
(.003)\end{array}$ & $\begin{array}{l}-.046 \\
(.008)\end{array}$ & $\begin{array}{l}-.064 \\
1.0101\end{array}$ & $\begin{array}{c}-.098 \\
(.014)\end{array}$ \\
\hline \multirow[t]{2}{*}{21 - 30 Years } & 1979 & $\begin{array}{l}-.078 \\
(.010)\end{array}$ & $\begin{array}{c}.020 \\
(.013)\end{array}$ & $\begin{array}{l}-.034 \\
(.008)\end{array}$ & $\begin{array}{l}-110 \\
1.002\end{array}$ & $\begin{array}{l}-.139 \\
(.009)\end{array}$ & $\begin{array}{l}-.139 \\
1.016)\end{array}$ \\
\hline & 1981 & $\begin{array}{l}-.026 \\
1.0094\end{array}$ & $\begin{array}{c}.118 \\
(.011)\end{array}$ & $\begin{array}{l}.016 \\
(.003)\end{array}$ & $\begin{array}{l}. .064 \\
(.007)\end{array}$ & $\begin{array}{l}-.077 \\
(.011)\end{array}$ & $\begin{array}{l}-.090 \\
(.016)\end{array}$ \\
\hline \multirow[t]{3}{*}{ Over 30 Yeers } & 1978 & $\begin{array}{l}-.087 \\
(.008)\end{array}$ & $\begin{array}{c}.002 \\
(.011)\end{array}$ & $\begin{array}{l}.071 \\
(.004)\end{array}$ & $\begin{array}{l}. .134 \\
(.002)\end{array}$ & $\begin{array}{l}-161 \\
(.008)\end{array}$ & $\begin{array}{c}-.147 \\
(.014)\end{array}$ \\
\hline & 1991 & $(.004)$ & $\begin{array}{c}.097 \\
(.012)\end{array}$ & $\begin{array}{l}.087 \\
(.003)\end{array}$ & $\begin{array}{l}-.020 \\
1.007)\end{array}$ & $\begin{array}{l}-.084 \\
(.012)\end{array}$ & $\begin{array}{l}.071 \\
(.016)\end{array}$ \\
\hline & & \multicolumn{6}{|c|}{ Women } \\
\hline \multirow[t]{2}{*}{10 or Lose Yoere } & 1979 & $\begin{array}{c}.055 \\
(.006)\end{array}$ & $\begin{array}{c}.065 \\
(.006)\end{array}$ & $\begin{array}{c}.051 \\
(.003)\end{array}$ & $\begin{array}{c}.039 \\
(.004)\end{array}$ & $\begin{array}{c}.020 \\
(.006)\end{array}$ & $\begin{array}{l}.004 \\
1.012\end{array}$ \\
\hline & 1991 & $\begin{array}{c}.018 \\
(.008)\end{array}$ & $\begin{array}{l}.049 \\
(.010)\end{array}$ & $\begin{array}{c}.038 \\
(.004)\end{array}$ & $\begin{array}{l}.013 \\
(.009)\end{array}$ & $\begin{array}{l}-.002 \\
1.0081\end{array}$ & $\begin{array}{l}-.005 \\
(.015)\end{array}$ \\
\hline \multirow[t]{2}{*}{11 - 20 Yeare } & 1978 & $\begin{array}{c}.020 \\
(.008)\end{array}$ & $\frac{.044}{(.006)}$ & $\begin{array}{l}.045 \\
(.004)\end{array}$ & $\begin{array}{c}.002 \\
(.006)\end{array}$ & $\begin{array}{l}. .020 \\
(.008)\end{array}$ & $\begin{array}{l}-.057 \\
(.015)\end{array}$ \\
\hline & 1891 & $\begin{array}{c}.004 \\
1.007\end{array}$ & $\begin{array}{c}.001 \\
(.009)\end{array}$ & $\begin{array}{c}.074 \\
(.004)\end{array}$ & $\begin{array}{c}.013 \\
(.008)\end{array}$ & $\begin{array}{l}-.048 \\
(.008)\end{array}$ & $\begin{array}{l}.073 \\
(.013)\end{array}$ \\
\hline \multirow[t]{2}{*}{21 - 30 Yeore } & 1978 & $\begin{array}{c}.032 \\
(.008)\end{array}$ & $\begin{array}{c}.051 \\
(.007)\end{array}$ & $\begin{array}{c}.068 \\
(.004)\end{array}$ & $\begin{array}{c}.043 \\
(.005)\end{array}$ & $\begin{array}{l}.002 \\
1.009)\end{array}$ & $\begin{array}{l}-.002 \\
1.017\end{array}$ \\
\hline & 1881 & $\begin{array}{c}.042 \\
(.008)\end{array}$ & $\begin{array}{c}.138 \\
(.010)\end{array}$ & $\begin{array}{l}.110 \\
(.004)\end{array}$ & $\begin{array}{l}.086 \\
(.008)\end{array}$ & $\begin{array}{l}-.018 \\
(.008)\end{array}$ & $\begin{array}{l}\cdot .068 \\
(.014)\end{array}$ \\
\hline \multirow[t]{2}{*}{ Over 30 Yoers } & 1879 & $\begin{array}{l}.072 \\
(.007)\end{array}$ & $\begin{array}{c}.087 \\
(.008)\end{array}$ & $\begin{array}{l}.085 \\
(.004)\end{array}$ & $\begin{array}{c}.081 \\
(.004)\end{array}$ & $\begin{array}{l}.045 \\
(.008)\end{array}$ & $\begin{array}{l}-.000 \\
1.0161\end{array}$ \\
\hline & 1981 & $\begin{array}{c}.085 \\
1.0084\end{array}$ & $\begin{array}{r}118 \\
.011)\end{array}$ & $\begin{array}{c}131 \\
(.005)\end{array}$ & $\begin{array}{l}108 \\
(.009)\end{array}$ & $\begin{array}{c}.051 \\
(.009)\end{array}$ & $\begin{array}{c}.007 \\
(.015)\end{array}$ \\
\hline
\end{tabular}

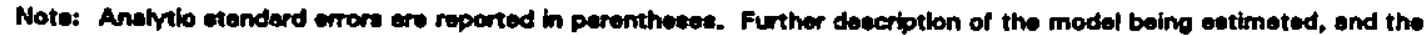
date set, lo provided in the text. 
33

Table 7: Ocoupetion-Specifle Eatimates of Publio Sector Wage Pramio

\begin{tabular}{|c|c|c|c|c|c|c|}
\hline \multirow[b]{3}{*}{ Ocoupation } & \multicolumn{3}{|c|}{$1978 / 1880$} & \multicolumn{3}{|c|}{$1990 / 1891$} \\
\hline & \multicolumn{2}{|c|}{ Mumber of Obeervations } & \multicolumn{4}{|c|}{ Number of Obeorvatione } \\
\hline & Publio & Pitvate & Promium & Publie & Pitvate & Promium \\
\hline & \multicolumn{6}{|c|}{ Male } \\
\hline Doctor & 128 & 302 & $\begin{array}{r}. .009 \\
(.0031\end{array}$ & 140 & 377 & $\begin{array}{l}.063 \\
(.061)\end{array}$ \\
\hline Bue Driver & 301 & 281 & $\begin{array}{l}. .048 \\
1.0341\end{array}$ & 276 & 277 & $\begin{array}{l}.086 \\
(.036)\end{array}$ \\
\hline Truck Driver & 378 & 4778 & $\begin{array}{l}-.191 \\
(.021)\end{array}$ & 287 & 6648 & $\begin{array}{c}-.017 \\
(.024)\end{array}$ \\
\hline Orderlie: & 169 & 181 & $\begin{array}{r}.173 \\
(.0321\end{array}$ & 103 & 248 & $\begin{array}{l}.173 \\
(.041)\end{array}$ \\
\hline Cleaners & 1364 & 3094 & $\begin{array}{l}.021 \\
(.0111\end{array}$ & 1080 & 2777 & $\begin{array}{l}.081 \\
(.014)\end{array}$ \\
\hline $\begin{array}{c}\text { Primary Secondary } \\
\text { Teachore }\end{array}$ & 2413 & 357 & $\begin{array}{l}.164 \\
(.021)\end{array}$ & 2070 & 647 & $\begin{array}{r}.168 \\
(.020)\end{array}$ \\
\hline \multirow[t]{2}{*}{ Poet-Secondery Toochere } & 806 & 332 & $\begin{array}{l}.072 \\
(.028)\end{array}$ & 826 & 410 & $\begin{array}{l}.081 \\
(.028)\end{array}$ \\
\hline & & \multicolumn{5}{|c|}{ Fornate } \\
\hline Regiatered Nurses & 720 & 2814 & $\begin{array}{r}.009 \\
(.012)\end{array}$ & 620 & 3839 & $\begin{array}{r}-.024 \\
(.014)\end{array}$ \\
\hline Practlesl Nursot & 188 & 888 & $\begin{array}{l}.036 \\
(.023)\end{array}$ & 141 & 958 & $\begin{array}{l}.023 \\
(.0261\end{array}$ \\
\hline Secroterios & 2093 & 8648 & $\begin{array}{l}-.034 \\
(.007)\end{array}$ & 1848 & 7576 & $\begin{array}{l}-.000 \\
1.0091\end{array}$ \\
\hline Roceptionista & 188 & 1633 & $\begin{array}{c}.015 \\
(.021)\end{array}$ & 162 & 1806 & $\begin{array}{l}.042 \\
1.0251\end{array}$ \\
\hline Typlate & 740 & 1818 & $\begin{array}{l}.042 \\
(.012)\end{array}$ & 387 & 960 & $\begin{array}{l}-.001 \\
(.0201\end{array}$ \\
\hline Orderites & 664 & 2200 & $\begin{array}{r}.128 \\
(.011)\end{array}$ & 546 & 2883 & $\begin{array}{r}.080 \\
(.017)\end{array}$ \\
\hline Clasner: & 683 & 2186 & .044 & 448 & 2454 & $\begin{array}{r}.006 \\
(.017)\end{array}$ \\
\hline $\begin{array}{c}\text { Primary a secondary } \\
\text { Teechers }\end{array}$ & 6408 & 1201 & $\begin{array}{c}.283 \\
(.013)\end{array}$ & 6787 & 1870 & $\begin{array}{c}.337 \\
(.012)\end{array}$ \\
\hline Poet-Secondery Teectiere & 396 & 186 & $\begin{array}{l}.133 \\
(.043)\end{array}$ & 877 & 260 & $\begin{array}{l}-.023 \\
(.038)\end{array}$ \\
\hline
\end{tabular}

Notee: Premin ere calculated ualng en ordinery loest equeres procedure on date from CPS Outgolng Rotetion Groupe for

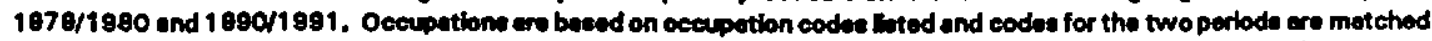
besed on thiles. The prinery and secondery teechers category atso hebudes pro-kindergarten and epecial educetion

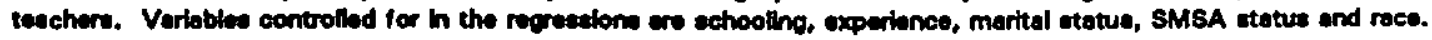
stenderd ecrore ere reported in perenthecee. 
FIgure 1A: Wage Premla for State and Local Workers men, 1979-1992

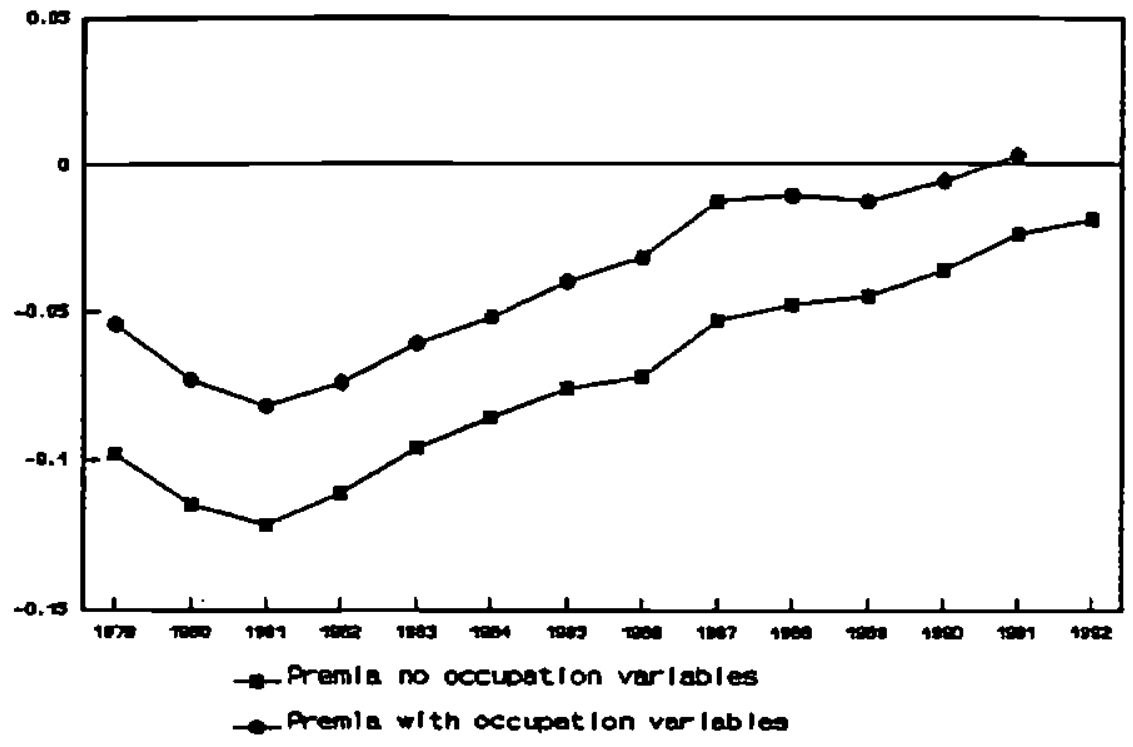

Floure 19: Wage Premla for State and Locel Workers momen, 1979-1992

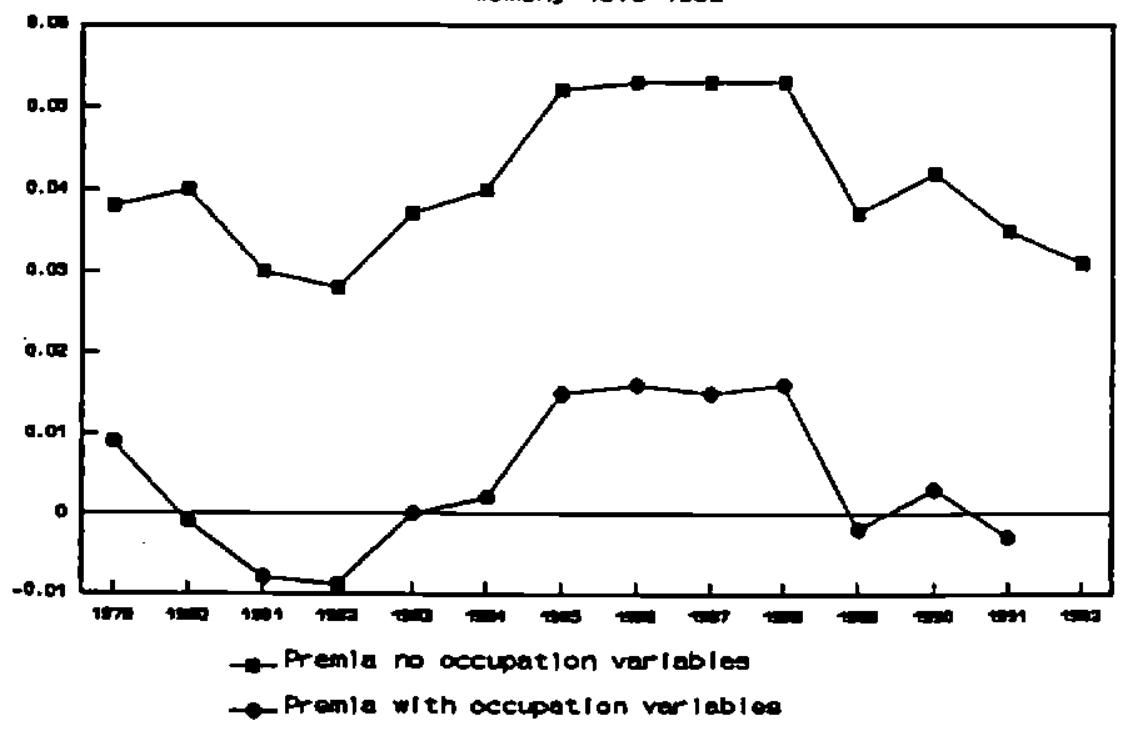




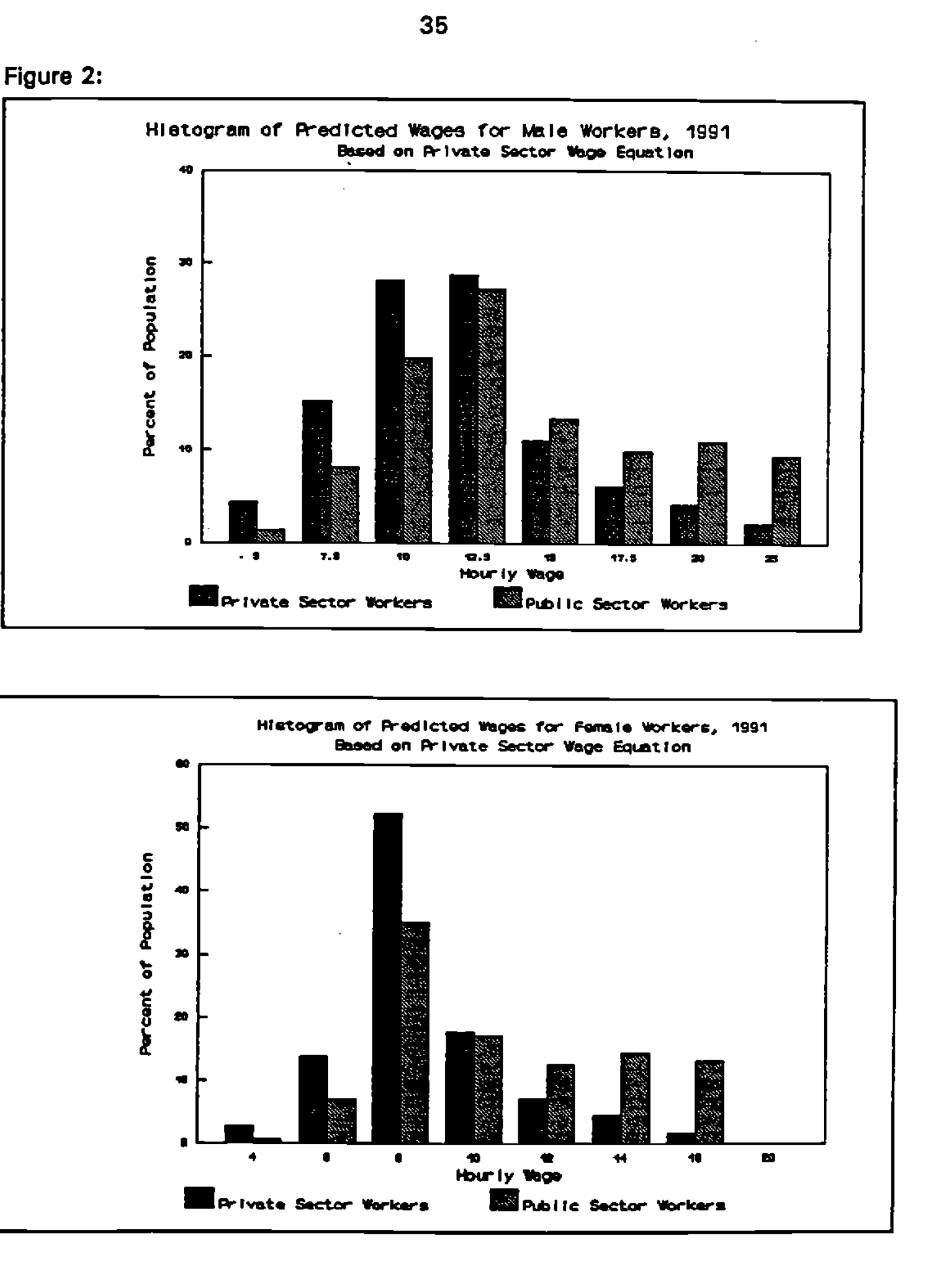



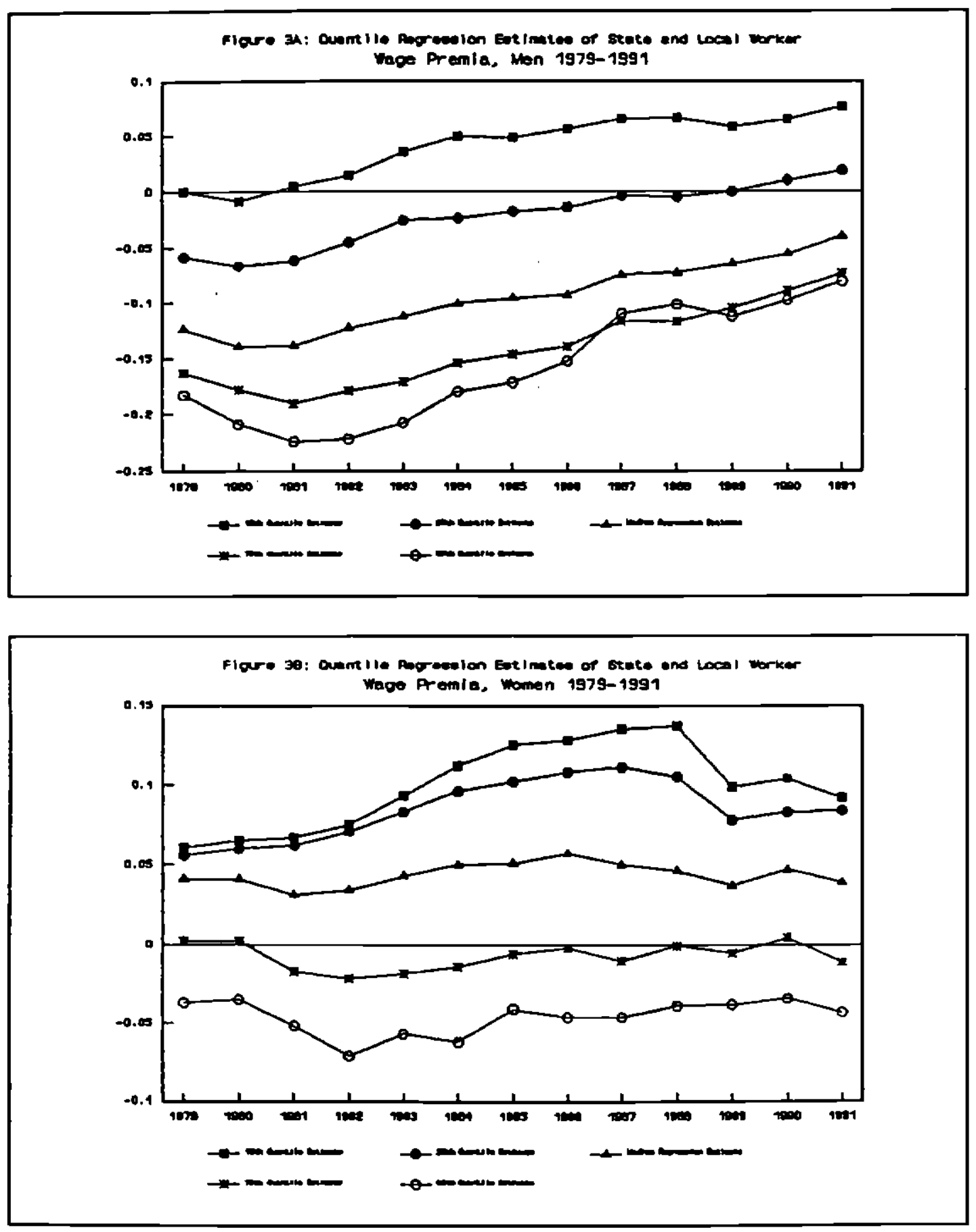
Appendlx: Changes in CPS Coding of Education, Pre- and Post-1992

In 1992, the Bureau of Labor Statlstics changed the Current Population Survey questions concerning educational attainment. Prior to 1992, the questions focused on number of years of school attended, and whether the respondent had completed the final year of schooling. Beginning in 1992, the survey asked about the highest grade of school attended. The modified questionnaire also grouped some potential responses on years of schooling, such as grades 1-4 and grades 5-6.

These changes makes it impossible to estimate the same wage equation on CPS data before 1992, and for 1992 and subsequent years. Jaeger (1993) presents some evidence on the relative performance of wage equations estimated with the two sets of educational variables. In this appendix, we present summary information on the distribution of responses to the two sets of surveys, and the pattern of responses for those who were included in both the 1991 and 1992 Current Population Surveys.

Table A- 1 shows the distribution of responses across education categories for respondents in the 1990, 1991, and 1992 Current Population Surveys. The pre-1992 respondents are classified by number of years of education completed, while the 1992 respondents are categorized by highest grade attended. There are two differences of note. First, the fraction of 1990/1991 respondents who are classified as having twelve years of schooling is more than two percent greater than that in 1992. This Is offset by a higher fraction of the 1992 respondents who appear to have attended some college, but do not have a college degree. Second, the 1992 survey reveals a higher fraction of respondents with sixteen years of schooling, and a lower fraction with post-graduate degrees. 
To provide further Information on the nature of the response changes, Table A2 reports a cross-tabulation of responses to education questions for respondents who were in the Current Population Survey in two consecutive years. The column labelled $1990 / 1991$ shows the degree of agreement between responses to the same survey instrument, pertaining to the same individual, In two consecutive years. For most levels of educational attainment, the agreement rates are greater than $95 \%$, with the notable exception of the 11 or 12 years of schooling (no high school degree) category. The incidence of identical responses is $94 \%$ for those completing 12 years of high school, and $97 \%$ for those with 16 years of schooling.

Table A-2 also shows the degree of agreement in education responses for individuals who were surveyed with different Instruments in 1991 and 1992 . The incidence of identical responses for those with 1991 responses shwoing fewer than twelve years of education completed is less than $70 \%$. Since the $1990 / 1991$ crosstabulation suggests there is relatively little pure measurement error in these questions, these results suggest substantive differences in the responses to the two sets of questions. There is a higher degree of agreement in responses for those who completed high school, with $90 \%$ of the 1991 respondents in this category classified the same way in 1992. For those recorded as having 16 years of schooling in 1991 , however, oniy $79 \%$ were coded as having a B.A. degree in 1992. 
Appendix Table A-1: Tabulations of Educational Attainment Variables, 1990-1992 Current Population Surveys

\begin{tabular}{|c|c|c|c|c|c|c|c|}
\hline $\begin{array}{l}\text { Years of } \\
\text { Education } \\
\text { Completed } \\
\text { (Pre-1992) }\end{array}$ & $\begin{array}{c}\text { Highest Grade } \\
\text { Attended } \\
\text { (Post-1991) }\end{array}$ & 1990 & 1991 & 1992 & 1990 & Women & 1992 \\
\hline 0 & 0 & 0.3 & 0.2 & 0.3 & 0.2 & 0.2 & 0.1 \\
\hline $1-4$ & $1-4$ & 0.6 & 0.7 & 0.7 & 0.4 & 0.4 & 0.3 \\
\hline $5-6$ & $5-6$ & 1.4 & 1.3 & 1.3 & 0.7 & 0.7 & 0.7 \\
\hline $7-8$ & $7-8$ & 2.5 & 2.6 & 2.2 & 1.5 & 1.5 & 1.5 \\
\hline 9 & 9 & 2.0 & 1.9 & 2.1 & 1.4 & 1.3 & 1.4 \\
\hline 10 & 10 & 3.6 & 3.4 & 3.5 & 3.0 & 2.7 & 2.8 \\
\hline $\begin{array}{l}11,12 \text { (Not } \\
\text { Completed) }\end{array}$ & $\begin{array}{l}11,12 \text { No } \\
\text { Diploma }\end{array}$ & 4.1 & 3.8 & 5.1 & 3.7 & 3.5 & 4.5 \\
\hline 1.2 (Completed) & $\begin{array}{l}\text { High School } \\
\text { Degree/GED }\end{array}$ & 37.0 & 36.2 & 34.5 & 39.7 & 39.1 & 36.3 \\
\hline $13-15$ & $\begin{array}{l}\text { Some College } \\
\text { (no degree). } \\
\text { Associates } \\
\text { Degree }\end{array}$ & 22.3 & 22.3 & 25.6 & 25.7 & 26.1 & 29.2 \\
\hline 16 & B.A. Degree & 14.6 & 15.3 & 16.4 & 14.2 & 14.7 & 16.2 \\
\hline $17+$ & $\begin{array}{c}\text { Post-Graduate } \\
\text { Degree }\end{array}$ & 11.4 & 12.2 & 8.6 & 9.6 & 9.9 & 6.6 \\
\hline
\end{tabular}

Notes: Levels are from tabulations run on data from the Outgoing Rotation Groups of the CPS. 1990, 1991 CPS's surveyed the number of years of school completed. The 1992 CPS surveyed the highest grade completed. These questions can produce different results. 
40

Appendix Table A-2: Tabulations of Educational Attainment Match Rates, 1990/1991 and 1991/1992 Current Population Surveys, Male Respondents

\begin{tabular}{l|l|ll}
\hline Years of Education & Highest Grade Attended & $1990 /$ & $1991 /$ \\
Completed (Pre-1992) & (Post-1991) & 1991 & 1992 \\
\hline 0 & 0 & $100 \%$ & $71 \%$ \\
$1-4$ & $1-4$ & 97 & 71 \\
$5-6$ & $5-6$ & 96 & 70 \\
$7-8$ & $7-8$ & 97 & 75 \\
9 & 9 & 98 & 58 \\
10 & 10 & 97 & 66 \\
11,12 (Not & 11,12 No Diploma & 74 & 66 \\
Completed) & High School Degree/GED & 94 & 90 \\
12 (Completed) & Some College (no degree), & 95 & 77 \\
$13-15$ & Associates Degree & & \\
16 & B.A. Degree & 97 & 79 \\
$17+$ & Post-Graduate Degree & 92 & 92 \\
\hline
\end{tabular}

Notes: Match rates are for male respondents who were in the fourth month rotation in the earlier year and the eight month rotation of the second year listed. Individuals were matched based on household identification number, age, race and relation to reference person. In both 1990/1991 and 1991/1992, about half of all possible respondents matched. Percentages listed are the match rates of the latter year category with the earlier year category. For example, the number listed for 16 and BA degree is the percent of respondents who responded that they had a BA in 1992, and who also responded they had 16 years of education. (This entry is not the percent of people who had 16 years of education who have a bachelor's degree.) 